\title{
COMMENT ON THE ARTICLE «SOLID CaCO3 FORMATION IN WATERS OF CIRCULATING COOLING SYSTEMS OF POWER PLANTS UNDER THE CONDITIONS OF ELECTRIC LOAD CHANGE» [Water and water purification technologies. Scientific and technical news. Vol. 23, № 2 (2018), pp. 12-21. DOI: https://doi.org/10.20535/2218-93002322018144957]
}

\author{
V. Z. Kochmarskii \\ National University of Water and Environmental Engineering, \\ Physical and Technological Laboratory of Water Systems. Rivne, Ukraine \\ e-mail: v.z.kochmarskii@nuwm.edu.ua
}

In article [Kochmarskii, 2018 ] in the analysis of the $I_{s t}$ stability index and the rate of the formation of calcium carbonate $D_{v e}$ from circulated water $(C W)$ of the cooling systems of electric power stations with cooling towers under changeable electric load Ne the direct dependence of dynamic parameter $\boldsymbol{\varphi}$ on Ne has not been taken into account. In some cases this led to inadequate reflection of $I_{s t}(\mathrm{Ne})$ and $D_{v e}(\mathrm{Ne})$ dependences. This inadequacy has been taken into account and proper laws of the expected value have been obtained. It was shown that the rate of the formation of calcium carbonate $D_{v e}$ is proportional to the electric load of the electric power station, to the concentration of $\mathrm{Ca}^{2+}$ ions in feed water and to the fraction of the heat used which is dispersed by evaporation at cooling towers, and it is inversely proportional to the water volume of circulated cooling system (CCS) and the average efficiency (AE) of the station.

Key words: Calcium carbonate; circulated water; condensation power stations; electric load; evaporation; rate of $\mathrm{CaCO}_{3}$ formation; stability index.

\section{Introduction}

In a previous article [Kochmarskii, 2018] the actual task of calculating stability index $\mathrm{I}_{\mathrm{st}}(\mathrm{Ne})$ and formation rate of $\mathrm{CaCO}_{3}$ from waters of CCS of electric power stations (EPS), in particular such ones, which are equipped with cooling towers, under conditions of changeable electric load were discussed. However, in [Kochmarskii, 2018] in modeling this regime the dependence of dynamic parameter $\varphi$ on electric load which led to the inadequate reflection of $I_{s t}(\mathrm{Ne})$ and $\mathrm{D}_{\mathrm{ve}}(\mathrm{Ne})$ dependences have not been taken into account.

In this article for modeling dependences $\mathrm{I}_{\mathrm{st}}(\mathrm{Ne})$ and $\mathrm{D}_{\mathrm{ve}}(\mathrm{Ne})$ we use basic formulas (3), (6), (7), (8a), (9), (11) and (12), obtained in [Kochmarskii, 2018]. For a stable regime of CCS and the established law of $\mathrm{CaCO}_{3}$ formation from $\mathrm{CW}$, see (11) from [Kochmarskii, 2018], taking into account the evident dependence $\boldsymbol{\varphi ( N e )}$ which as it follows from (1) and is related to the expenditure of $\mathrm{CW}$ and evaporation $\mathrm{G}_{\mathrm{ev}}(\mathrm{Ne})$,

$$
\begin{gathered}
\varphi(\mathrm{Ne})=\frac{\mathrm{G}_{\mathrm{f}}}{\mathrm{G}_{\mathrm{f}}-\mathrm{G}_{\mathrm{ev}}(\mathrm{Ne})} ; \quad \mathrm{I}_{\mathrm{st}}(\mathrm{Ne})=\frac{1}{1+\varphi(\mathrm{Ne}) \cdot \mathrm{T}_{\mathrm{f}} \cdot \mathrm{K} \cdot \mathrm{C}_{\mathrm{HCO} 3 \infty} ;} \quad \mathrm{T}_{\mathrm{f}}=\frac{\mathrm{V}}{\mathrm{G}_{\mathrm{f}}} \\
\mathrm{D}_{\mathrm{ve}}(\mathrm{Ne})=\frac{\mathrm{dC}_{\mathrm{Cass}}}{\mathrm{dt}}=\frac{\mathrm{C}_{\mathrm{Ca} 0}}{\mathrm{~T}_{\mathrm{f}}} \cdot\left[1-\mathrm{I}_{\mathrm{st}}(\mathrm{Ne})\right]=\frac{\varphi(\mathrm{Ne}) \cdot \mathrm{K} \cdot \mathrm{C}_{\mathrm{Ca} 0} \cdot \mathrm{C}_{\mathrm{HCO} 300}}{1+\varphi(\mathrm{Ne}) \cdot \mathrm{K} \cdot \mathrm{T}_{\mathrm{f}} \cdot \mathrm{C}_{\mathrm{HCO} 300}}
\end{gathered}
$$

$\mathrm{G}_{\mathrm{f}}, \mathrm{G}_{\mathrm{ev}}$ - correspondingly, the expenditure of water for feeding and evaporation, $\mathrm{m}^{3} /$ hour; $\mathrm{C}_{\text {Cass }}-$ molar concentration of solid $\mathrm{CaCO}_{3}$ that is formed from $\mathrm{CW}, \mathrm{g}-\mathrm{mole} / \mathrm{m}^{3} ; \mathrm{C}_{\mathrm{HCO} 300}, \mathrm{C}_{\mathrm{Ca} 0} 0^{-}$ concentrations of bicarbonate and calcium ions in stationary $\mathrm{CW}$ and in feed water, $(\mathrm{g}$-ions $) / \mathrm{m}^{3} ; \mathrm{K}$ - kinetic coefficient of the reaction of forming $\mathrm{CaCO}_{3}$ under the interaction of $\mathrm{Ca}^{2+}$ and $\mathrm{HCO}_{3}{ }^{-}$ions 
in the adopted in [Kochmarskii, 2018] model of the formation of calcium carbonate. $\mathrm{K}$ is determined by a special procedure for water of acting or designed CCS. For non-stabilized by inhibitors waters K $=(1.5 \ldots 4.4) \cdot 10^{-4} \mathrm{~m}^{3} /(\mathrm{g}$-ions $)$ hour, for stabilized ones it may be three-four times less [Gayevskii, 2018]. It is shown in [Kochmarskii, 2018] that the direct dependence of water expenditure for evaporation on electric load is given by the expressions

$$
\mathrm{G}_{\mathrm{ev}}(\mathrm{Ne})=\mathrm{K}_{\mathrm{ev}} \cdot \mathrm{A}(\eta) \cdot \mathrm{Ne}, \quad \mathrm{A}(\eta)=3600 \cdot \frac{(1 / \eta-1)}{\rho_{\mathrm{w}} \cdot \mathrm{r}_{\mathrm{w}}}, \quad \eta=\frac{\mathrm{Ne}}{\sum \frac{\mathrm{Ne}_{\mathrm{i}}}{\eta_{\mathrm{i}}}}
$$

$\mathrm{K}_{\mathrm{ev}}$ - coefficient of evaporation is equal to the heat part formed in a turbine condenser which is transferred in cooling towers by evaporation, this value depends on the temperature of $\mathrm{CW}$ and surrounding conditions is changed [Laptiev, Vedgaieva, 2004] within boundaries of $0.30<\mathrm{K}_{\mathrm{ev}}<$ $0.87 ; \rho_{\mathrm{w}}, \mathrm{r}_{\mathrm{w}}$ - correspondingly, water density and specific heat of evaporation under temperature of $\mathrm{CW} ; \mathrm{Ne}=\Sigma \mathrm{N}_{\mathrm{i}}$ - total electric load of the station, MW; $\eta-\mathrm{AE}$ at the station; $\mathrm{A}(\eta)$ - quantity of evaporated water, $\mathrm{m}^{3}$ per $1 \mathrm{MW}$.hour of heat dispersed by cooling towers, $\mathrm{A}=(2.3 \ldots 3.1)$ $\mathrm{m}^{3} /(\mathrm{MW} \cdot$ hour).

Coefficient of evaporation $\mathrm{K}_{\mathrm{ev}}$ from (3) may be calculated on the basis of the mathematical model of the cooling process in a cooling tower, or determined by a special procedure [Laptiev, Vedgaieva, 2004]. Other values in (3) are tabular, or belong to such ones which are measured by the control regulation of the regime of stations operation.

\section{Simulation}

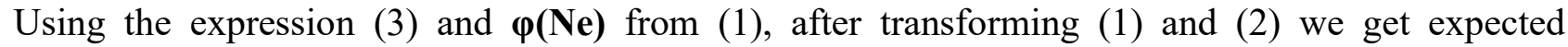
dependences

$$
\begin{array}{r}
I_{\mathrm{st}}(\mathrm{Ne})=\frac{\mathrm{G}_{\mathrm{f}}-\mathrm{K}_{\mathrm{ev}} \cdot \mathrm{A}(\eta) \cdot \mathrm{Ne}}{\mathrm{G}_{\mathrm{f}}-\mathrm{K}_{\mathrm{ev}} \cdot \mathrm{A}(\eta) \cdot \mathrm{Ne}+\mathrm{V} \cdot \mathrm{K} \cdot \mathrm{C}_{\mathrm{HCO} 300}} \\
\mathrm{D}_{\mathrm{ve}}(\mathrm{Ne})=\mathrm{G}_{\mathrm{f}} \cdot \frac{\mathrm{K} \cdot \mathrm{C}_{\mathrm{Ca} 0} \cdot \mathrm{C}_{\mathrm{HCO} 000}}{\mathrm{G}_{\mathrm{f}}-\mathrm{K}_{\mathrm{ev}} \cdot \mathrm{A}(\eta) \cdot \mathrm{Ne}+\mathrm{V} \cdot \mathrm{K} \cdot \mathrm{C}_{\mathrm{HCO} 300}} .
\end{array}
$$

As in [Kochmarskii, 2018] we use obtained here expressions (4) and (5) to analyze the operation of EPS [Kochmarskii at al, 2014] in CCS of which partial softening of feed water, cooling towers and also inhibitors of deposits are used. For calculations we adopt: $\mathrm{Ne}=(300 \ldots 1200) \mathrm{MW} ; \varphi_{\mathrm{oo}}=2.8 \ldots 3.8$; $\mathrm{V}=(200 \ldots 280) \cdot 10^{3} \mathrm{~m}^{3} ; \mathrm{K}=(1.1 \ldots 4.4) \cdot 10^{-4} \mathrm{~m}^{3} /(\mathrm{g}$-ions $) \cdot$ hour; $\mathrm{C}_{\mathrm{Ca} 0}=0.7(\mathrm{~g}$-ions $) / \mathrm{m}^{3}, \mathrm{C}_{\mathrm{HCO} 3 \mathrm{oo}}=7(\mathrm{~g}-$ ions $) / \mathrm{m}^{3}, \mathrm{~A}(\eta)=2.63 \mathrm{~m}^{3} / \mathrm{MW} \cdot$ hour. Calculation results are shown below.

We see from fig. 1, with the increased parameter $\mathrm{K}$ (decreased dosage of $\mathrm{CaCO}_{3}$ inhibitor), which controls the rate of $\mathrm{CaCO}_{3}$ formation, see curves $1 \ldots 4$, stability index of $\mathrm{CW}$ is reduced expectedly. Such behavior of stability index is the same with the increased electric load Ne. That is, the operation of EPS under the maximum load is accompanied by the maximum decreased stability of circulated water. However, from fig. 2 we see that the stability of CW is increased with the growth of AE of the station. Hence, the decreased stability of CW due to the growth of load of EPS is partially compensated by its AE increase, see fig. 2.

Interesting is the dependence of $\mathrm{I}_{\mathrm{st}}\left(\mathrm{G}_{\mathrm{f}}\right)$ shown in fig. 3. The stability of $\mathrm{CW}$ increases with the increased consumption of feed water.

This conclusion is not evident and it is to be considered while using the recirculation of the blowthrough which decreases the consumption of fresh water in CCS. That is, in using such an approach it is necessary to consider the possible decreased stability of CW. The dependence $\mathrm{I}_{\mathrm{st}}(\mathrm{Kev})$ is shown in fig. 4. We see that the operation of CCS under increased coefficient of evaporation leads to 
decreased stability index. Such regime is implemented under high temperatures of CW (in summer). It is evident that the winter period of CCS operation contributes to the high stability index.

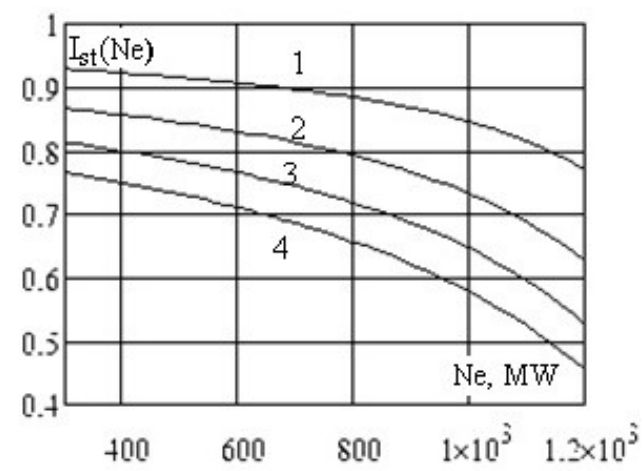

Fig. 1. Dependence of stability index on electric load. Curves $1 . . .4$ correspond to value of constant $\mathrm{K}=(1.1 ; 2.2 ; 3.3 ; 4.4) \cdot 10^{-4} \mathrm{~m}^{3} /(\mathrm{g}$ ions) hour. Value of other parameters:

$\eta=0.35 ; \rho_{\mathrm{w}}=998 \mathrm{~kg} / \mathrm{m}^{3}, \mathrm{r}_{\mathrm{w}}=2.47 \mathrm{MJ} / \mathrm{kg} ; \mathrm{V}=$ $2.4 \cdot 10^{5} \mathrm{~m}^{3} ; \mathrm{G}_{\mathrm{f}}=3000 \mathrm{~m}^{3} /$ hour.

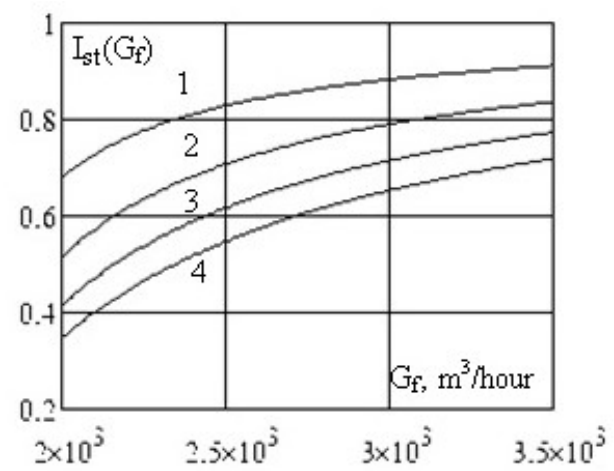

Fig. 3. Dependence of stability index on expenditure of replenished water. $\mathrm{Ne}=$ $800 \mathrm{MW} ; \eta=0.35$. Values of other parame-ters are the same as in fig. 1.

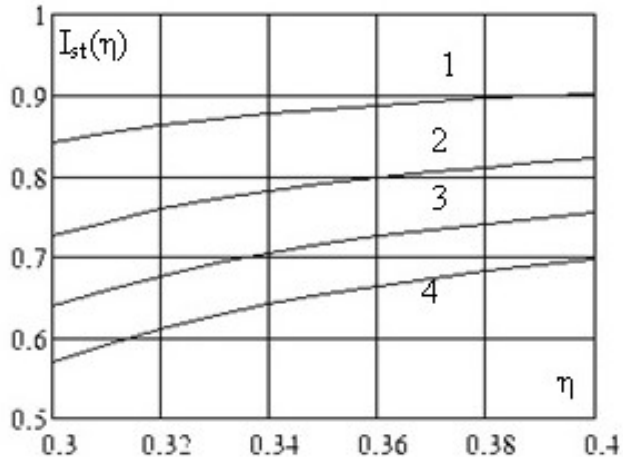

Fig. 2. Dependence of stability index on $A E$ at $\mathrm{Ne}=800 \mathrm{MW}$. Values of other parameters are the same as in fig.1.

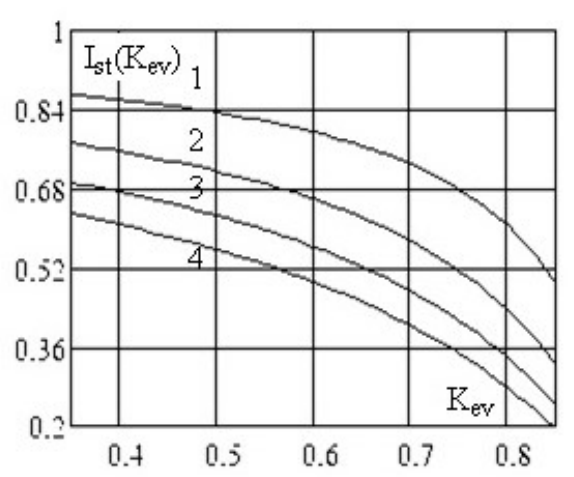

Fig. 4. Dependence of stability index on evaporation coefficient. $\mathrm{Ne}=800 \mathrm{MW} ; \eta=0.35$; $\mathrm{G}_{\mathrm{f}}=2000 \mathrm{~m}^{3} /$ hour. Values of other parameters are the same as in fig. 1 .

For example, by the data of fig. 4 we find that during the transition from winter operation regime to summer one, the stability index of CW decreases from 1.6 to 3.0 times. This fact is to be taken into account in planning the regime of stabilizing $\mathrm{CW}$ by inhibitors or in developing other measures of optimization of CCS operation regimes.

Let us analyze the behavior of the formation rate of $\mathrm{CaCO}_{3}$ from $\mathrm{CW}$ under different operation conditions of CCS. Calculations will be done by formula (5). Results are shown in fig. 5 and 6. From fig. 5 we see that the growth of the capacity of a station from 300 to $1200 \mathrm{MW}$ with $\mathrm{K}=1.1 .10^{-4} \mathrm{~m}^{3} /(\mathrm{g}$ ions) hour is accompanied by the increased rate of $\mathrm{CaCO}_{3}$ formation by 5 times, see curve 1 in fig.5, with $\mathrm{K}=2.2 .10^{-4} \mathrm{~m}^{3} /(\mathrm{g}$-ions $) \cdot$ hour - by 2.75 times, with $\mathrm{K}=3.3 .10^{-4} \mathrm{~m}^{3} /(\mathrm{g}$-ions $) \cdot$ hour - by 2.4 times and with $\mathrm{K}=4.4 .10^{-4} \mathrm{~m}^{3} /\left(\mathrm{g}\right.$-ions) hour by 2.2 times. That is, with great $\mathrm{K}$ the formation rate of $\mathrm{CaCO}_{3}$ becomes less sensitive to increased load of stations. The dependence $\mathrm{D}_{\mathrm{ve}}(\eta)$ is also noticeable. From fig. 6 we see that with the increased $\mathrm{AE}$ within the range of $0.3 \ldots 0.4$ the rate of $\mathrm{CaCO}_{3}$ formation decreases by 1.6 times. Comparing these dependences in fig. 5 and 6 we see that to compensate for the growth of the formation rate of calcium carbonate under the increased loading is impossible by the growth of CE.

Dependences in fig. 6 correlate with curves in fig. 3 and expressions (1) and (2) because the stability growth of $\mathrm{CW}$ is always accompanied by the decreased rate of $\mathrm{CaCO}_{3}$ formation. 
The decreased rate of $\mathrm{CaCO}_{3}$ formation with the $\mathrm{AE}$ growth, see fig. 6 , is explained by the fact that under the same capacity the growth of $\mathrm{AE}$ is accompanied by the expenditure of smaller quantity of water for evaporation, and under the stable feeding of $\boldsymbol{C C S}$ its blow-through grows $\left(\mathrm{G}_{\mathrm{f}}-\mathrm{G}_{\mathrm{ev}}=\mathrm{G}_{\mathrm{e}}\right)$ and, correspondingly, the concentration of $\mathrm{Ca}^{2+}$ and $\mathrm{HCO}_{3}{ }^{-}$ions capable to generate the deposition of $\mathrm{CaCO}_{3}$ decreases, see fig. 7 .

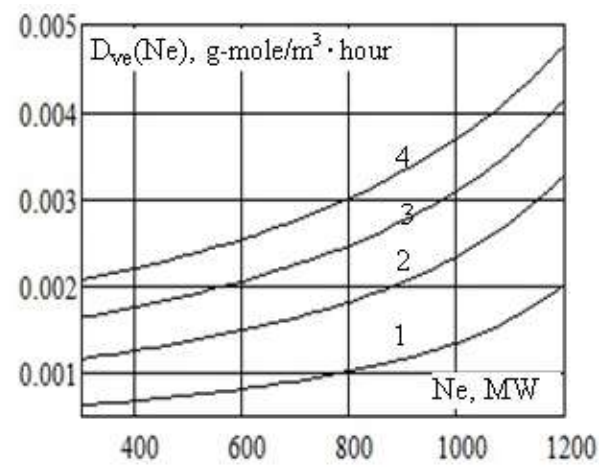

Fig. 5. Dependence of the rate of $\mathrm{CaCO}_{3}$ formation on electric power loading Ne. Curves 1 ...4 correspond to the value of constant $\mathrm{K}$ such as is in fig.1. Values of other parameters: $\eta=0.35 ; \rho_{\mathrm{w}}=$ $998 \mathrm{~kg} / \mathrm{m}^{3} ; \mathrm{r}_{\mathrm{w}}=2.5 \mathrm{MJ} / \mathrm{kg} ; \mathrm{V}=2.4 \cdot 10^{5} \mathrm{~m}^{3} ; \mathrm{G}_{\mathrm{f}}=3000 \mathrm{~m}^{3} /$ hour.

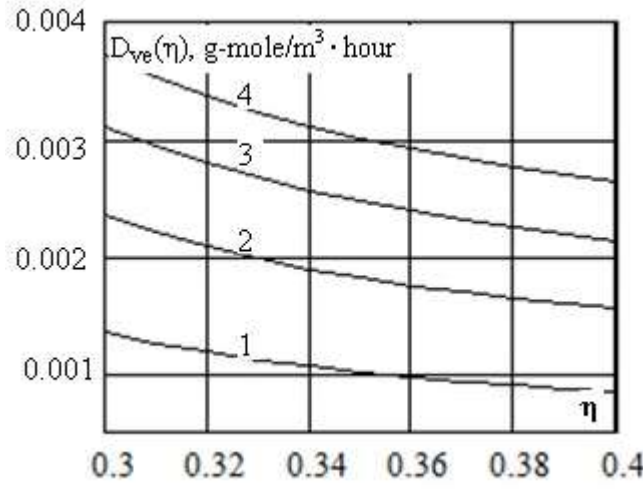

Fig. 6. Dependence of the rate of $\mathrm{CaCO}_{3}$ formation on $\mathrm{AE}$. $\mathrm{Ne}=800 \mathrm{MBT}$. Values of other parameters are the same as in fig. 5 .

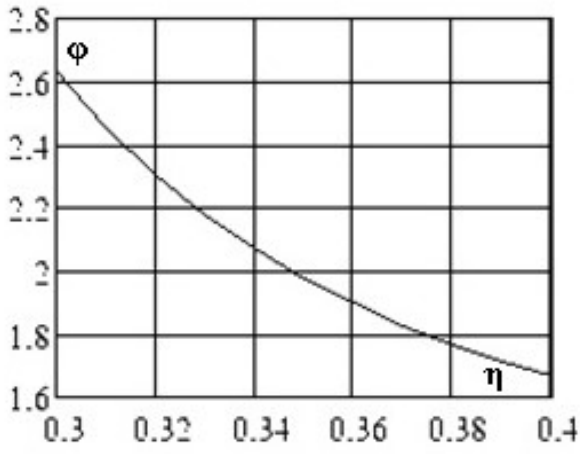

Fig. 7. Dependence of parameter $\varphi$ on AE of block, see (1) and (3). Values of other parameters are the same as in fig. 5.

We see that the growth of $\mathrm{AE}$ within the range of $30 \ldots 40 \%$ is accompanied by the decreased concentrations of ions by $\approx 1.6$ times.

Hence, in analyzing conditions of CCS operation and in calculating the rate of the formation of deposits it is necessary to consider changes in operation regimes of CCS due to the change of stations load which is accompanied by the change of evaporation of $\mathrm{CW}$ in cooling towers. This means that adequate mathematical model of CCS operation must consider the value of electric load and water regime of stations operation.

\section{Summary}

1. Basic parameters reflecting dependences $I_{s t}(\mathrm{Ne})$ and $D_{\text {ev }}(\mathrm{Ne})$ are water consumption for CCS feeding, AE of station $\eta$ and its electric load Ne. Besides, $I_{s t}(\mathrm{Ne})$ and $D_{\text {ev }}(\mathrm{Ne})$ parameters depend on the quality of $\mathrm{CW}$ and coefficient $\mathrm{K}$ that characterizes the rate of $\mathrm{CaCO}_{3}$ formation.

2. With increased electric load of the station the stability index of $\mathrm{CW}$ decreases and the rate of $\mathrm{CaCO}_{3}$ formation grows. On the contrary, with the growth of $\mathrm{AE}$ - the stability of $\mathrm{CW}$ grows and the rate of $\mathrm{CaCO}_{3}$ formation and the level of salts concentration reduce.

3. With decreased coefficient of evaporation $\mathrm{K}_{\mathrm{ev}}$ (CCS operation under decreased temperatures), stability index of $\mathrm{CW}$ grows, correspondingly, the rate of $\mathrm{CaCO}_{3}$ formation reduce. 
4. The proposed here methods of calculating $\mathrm{I}_{\mathrm{st}}(\mathrm{Ne})$ and $\mathrm{D}_{\mathrm{ev}}(\mathrm{Ne})$ allow us to make a quantitative forecast of $\mathrm{CW}$ stability in designing power stations on the basis of data about the quality of water at the local source of feeding and to substantiate the selection of optimum measures concerning the minimization of the rate of $\mathrm{CaCO}_{3}$ formation.

5. For the reliable forecast of $\mathrm{CW}$, stability for new stations it is necessary to have experimental studies concerning the determination of coefficient $\mathrm{K}$ in water that models $\mathrm{CW}$ of designed CCS.

6. Expressions (1) - (5) may be the basis for the technical and economic optimization of the process of minimizing deposits under the changeable CCS operation regimes, as well as for developing adequate mathematical models of automating the process of deposits control under such conditions.

\title{
References
}

Gayevskii V.R., Kochmarskii V.Z. The increase of the efficiency of circulated systems of cooling by minimizing calcium-carbonate deposits. Rivne: National University of Water and Environmental Engineering (2018), 154p. ISBN 978-966-327-383-9 (Ukraine languish).

Kochmarskii V.Z. Solid $\mathrm{CaCO}_{3}$ formation in waters of circulated cooling systems of power plants under the conditions of electric load change.// Water and water purification technologies. Scientific and technical news. Vol. 23, № 2 (2018), pp. 12-21. DOI: https://doi.org/10.20535/221893002322018144957].

Kochmarskii V.Z., Kochmarskii O.V., Fesenko I.P. Dynamics of deposits inhibitor in circulated water of Zuyevskaja EPS// Power engineering and electrification. Nu 11 (2014), pp. 12-16.

Laptiev A.G.,. Vedgaieva I.A. The installation and design of industrial cooling towers. Kazan State Power Engineering University. Kazan (2004), 175p.

Received 27.12.2019

Revised 18.02.2020

Accepted 11.03.2020

\section{ЗАУВАЖЕННЯ ДО СТАТТІ «ВИДІЛЕННЯ ТВЕРДОГО СаСОЗ 3 ВОД ОБОРОТНИХ СИСТЕМ ОХОЛОДЖЕННЯ ЕЛЕКТРОСТАНЦІЙ В УМОВАХ ЗМІННОГО ЕЛЕКТРИЧНОГО НАВАНТАЖЕННЯ» [Water and water purification technologies. Scientific and technical news. T. 23, № 2 (2018), pp. 12-21. DOI: https://doi.org/10.20535/2218-93002322018144957]}

\author{
В. 3. Кочмарський \\ Національний університет водного господарства і природокористування, \\ Фізико-технологічна лабораторія водних систем. Рівне, Україна \\ e-mail: v.z.kochmarskii@nuwm.edu.ua
}

B [Kochmarskii, 2018] при аналізі індексу стабільності $I_{s t}$ та швидкості виділення карбонату кальиію $D_{\text {vе }}$ оборотної води (OB) систем охолодження електростанцій з градирнями при змінному електричному навантаженні Ne не було враховано явної залежності динамічного параметра $\varphi$ від Ne. Це призвело до неадекватного відображення залежностей $I_{s t}(\mathrm{Ne}) \mathrm{ma}$ $D_{v e}(\mathrm{Ne})$.

B даній роботі ия неточність врахована $і$ отримані коректні закони поведінки індексу

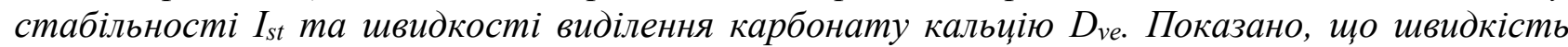

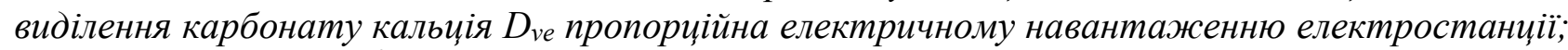
концентрації іонів $\mathrm{Ca}^{2+}$ у воді підживлення та частиі відпрацьованого тепла, щзо розсіюється випаровуванням на градирнях; обернено пропориійна водному об'єму оборотних систем охолодження та середньому ККД станиї. 
Індекс стабільності $O B$ з ростом електричного навантаження зменшується, проте, зі збільшенням ККД станиії стабільність ОВ зростає. Чисельне моделювання для конденсаційної електростанції 3 електричним навантаженням (300..1200)MBm, спорядженої градирнями, показало, щчо ріст стабільності ОВ завдяки росту ККд не компенсує його зменшення внаслідок збільшення навантаження станції. При роботі станиіі в умовах підвищеного випаровування (літній сезон) стабільність ОВ знижується. Підвищення подачі води підживлення при сталих режимах випаровування та виділення СаСО сприяє збільшенню стабільності ОВ (завдяки зменшенню коефічієнту концентрування солей).

Отримані тут вирази $I_{s t}(\mathrm{Ne})$ ma $\mathrm{D}_{\text {ve }}(\mathrm{Ne})$ дозволяють розрахувати необхідні дози інгібіторів відкладень та розробити проиедури для досягнення заданої стабільності ОВ. Вони будуть корисними при проектуванні нових станцій для покращення кількісного прогнозу стабільності ОВ на підставі даних про якість води місиевого джерела живлення. Їх можна застосовувати при обтрунтуванні вибору оптимальних заходів щуодо мінімізачії швидкості виділення $\mathrm{CaCO}_{3}$ в умовах змінного навантаження. Вирази $I_{s t}(\mathrm{Ne})$ ma $D_{v e}(\mathrm{Ne})$ будуть корисними при розробиі матмоделей автоматизації процесу контролю над відкладеннями.

Ключові слова: випаровування; карбонат кальцію; індекс стабільності; оборотна вода; швидкість виділення; електричне навантаження.

\title{
ЗАМЕЧАНИЕ К СТАТЬЕ «ВЫДЕЛЕНИИ ТВЕРДОГО СаСОз ИЗ ВОД ОБОРОТНЫХ СИСТЕМ ОХЛАЖДЕНИЯ ЭЛЕКТРОСТАНЦИЙ В УСЛОВИЯХ ПЕРЕМЕННОЙ ЭЛЕКТРИЧЕСКОЙ НАГРУЗКИ» [Water and water purification technologies. Scientific and technical news. T.23, № 2 (2018), pp. 12-21. DOI: https://doi.org/10.20535/2218- 93002322018144957]
}

\author{
В. З. Кочмарский \\ Национальный университет водного хозяйства и природопользования. \\ Физико-технологическая лаборатория водных систем. Ривне, Украина \\ e-mail: v.z.kochmarskii@nuwm.edu.ua
}

B [Kochmarskii, 2018] при анализе индекса стабильности $I_{s t}$ и скорости выделения карбоната кальиия $D_{\text {ve }}$ с оборотной воды (OB) систем охлаждения электростанциии с градирнями при переменной электрической нагрузке Nе явно не была учтена зависимость параметра $\varphi$ от Ne. Это привело в некоторых случаях к неадекватному отображению зависимостей $I_{s t}(\mathrm{Ne}) u$ $D_{v e}(\mathrm{Ne})$.

Здесь эта зависимость учтена и получены корректные количественные законь поведения искомых величин. Показано, что скорость вылеления карбоната кальция $D_{v e}(\mathrm{Ne})$ пропорчиональна электрической нагрузке электростанции, концентрации ионов $\mathrm{Ca}^{2+}$ в воде подпитки и части отработанной теплоты, рассеиваемой испарением в градирнях, обратно пропорииональна водному объему оборотной системы охлаждения и среднему КПД станции. Ключевые слова: испарение; карбонат кальция; индекс стабильности; оборотная вода; скорость выделения $\mathrm{CaCO}_{3}$; электрическая нагрузка. 